Metodički obzori 6(2011)2

Original scientific article

UDK: $373.24 .02 / .03$

Received: 5. 1. 2011.

\title{
COOPERATIVE LEARNING AND SUPPORT STRATEGIES IN THE KINDERGARTEN
}

\author{
Prof. Jurka Lepičnik Vodopivec, PhD \\ Pedagoška fakulteta \\ Univerza v Mariboru (Slovenia) \\ e-mail: jurka.lepicnik@uni-mb.si
}

\begin{abstract}
A b stract
In our article we examined the characteristics of cooperative learning and support strategies in the kindergarten system. A typical feature of active learning is constant creation of favourable environments that stimulate learning. An encouraging environment is a type of environment where positive social interactions and mutual trust are prevalent. In such environments children develop social skills and competences that significantly influence a child's development. Such conditions in the kindergartens are created by adults who try to identify special interests and skills of individual children and offer them adequate motivation and initiative for cooperative learning. Educators support cooperative learning of children in the kindergarten through special support strategies, such as organizing the space and the environment, establishing an atmosphere of positive social interaction, encouraging child's activities and thinking about and considering their interests and initiatives.
\end{abstract}

Key words: Cooperative learning, preschool child, kindergarten support strategies

\section{Introduction}

Cognitive theories that most often quote Piaget, Vygotsky and Bruner emphasize the child's active role in acquisition and construction of knowledge, difference in quality between a child's way of thinking at various development stages, the importance of an optimal - sensitive stage for specific types of learning and building on the child's internal motivation (http://www.pef.uni-lj.si/strani/ oddelki/ (2-pp-ucenje-vrtec.rtf). Piaget's theory is important because it points out the negative effects of ignoring children's cognitive development characteristics or outpacing that development. $\mathrm{He}$ believes that development is a spontaneous process based on a child's internal growth and exploration of the world. Vygotsky does not deny spontaneous development either, however he attributes it a smaller role than Piaget. Unlike Piaget, Vygotsky emphasizes the roles culture and language play in the process of cognitive development and in the process of learning. According to his opinion, learning is a social experience where adults play an important role. Hohmann and Weikart (2005) agree with his assessment and attribute an important role to the educator in preparing the environment for 
children's active learning, as the educator is the one who organizes the environment, establishes an atmosphere of positive social interaction, encourages children's activities pertaining to solving problems and verbal reasoning, monitors and interprets the activities of each child in the light of development principles and plans experiences that are based on children's activities and interests. The child is an active participant in this process, collecting information from the environment based on his age and development stage. Developing his abilities, with an inquisitive attitude toward the environment and the world around him, the child explores and learns the laws of nature and the society. New discoveries and realizations provoke qualitative changes in themselves. Therefore, in this process, a child is an active participant who also activates its own environment (Lepičnik Vodopivec, 2005). According to Marentič-Požarnik (2000), a child's activity is "the" factor of quality learning that activates the child as a whole, mentally and emotionally, which is why it is referred to as active learning. Learning is most successful if done through independent searching and thinking, in a meaningful dialogue, in a group, through experimentation. It is about actively making sense of things and linking the new with the already known, which also improves memory. Such learning very probably enables a more solid knowledge base and is useful in new situations.

Hohmann and Weikart (2005, pg. 16) define active learning as "targeted and direct experience of objects, people, ideas and events - it is a necessary requirement for cognitive transformation and development. Simply put, children learn concepts, create their own ideas and construct their own symbols or abstractions through activities which they initiate themselves - moving, listening, searching, feeling, explaining and shaking hands. Such activities, happening in a social framework, where an attentive and sensitive adult participates/observes, enable the child to have truly interesting experiences, which might lead to contrary conclusions and consequently to a reorganisation of the child's understanding of the world." The authors (Hohmann and Weikart, 2005) estimate that children in the process of active learning initiate activities that are based on their own interests and intentions, select materials and decide what to do with them, use all senses to actively examine the materials, explore relationships through direct experience with objects, reshape and combine materials, use age-suitable tools and equipment, talk about their own experience and use their own words to describe what they are doing.

\section{Cooperative learning and social skills}

Humans are social beings and life in a community and intensive interactions with other humans are prerequisites for our development and for achieving all of our potentials. Relationships with others are important during every stage of life - from the earliest stage in the family, later in the kindergarten, in school, with peers, with partners and at the workplace. The quality of these relationships and, through it, the success in life is to a large extent defined by our cooperation with those around us (Peklaj, 1998). Cooperation in this case pertains to joint actions to achieve a common goal. Cooperative learning defines methods used during the learning process, where we stimulate children or ask them to work together to carry out tasks (Peklaj, 2001, pg. 8). Kozel and Kmetec (2001/02) believe that cooperation is joint work to achieve a common goal. In a 
cooperative situation the goals of participants are positively connected with each other. Participants perceive that their goal is achievable only if other group members can achieve their goals as well. That is why, in a group, participants look for methods that are suitable for them and all other group members they cooperate with (Ibid.).

Hansen and Kaufmann (2000) estimate that child cooperation in the kindergarten enables them to: feel good, develop creativity and a feeling of productivity, develop strategies for coping with life's problems, develop a feeling of happiness and belonging, learn new skills, have fun and laugh, relax, make mutual acquaintances and similar.

To sum it up, life is a constant interaction with others; therefore it is important that we support children at the early childhood stage in developing social competences.

According to certain authors (Guralnick, 1990, Katz \& McClellan, 1997), listed by Han and Kemle (2006), early childhood competences are defined as skills that are realized by children interacting with their peers and with adults. According to the authors, social competences are:

Accepting social values, whereby this pertains to teaching justice, honesty, responsibility, a healthy way of life and sexual conduct as well as the ability to adapt.

Planning and decision making skills pertaining to making real and important decisions on where, what, how and with whom to play.

Positive self-image includes the feeling of skill, personal power and self-worth.

Cultural competences include acquisition of new skills, respect and successful interpersonal cooperation with people from different ethnic and racial backgrounds.

Self-control includes skills for controlling needs and emotions.

Interpersonal skills include understating of self and others and accepting the basic needs and emotions, changing the needs and emotions of others and cooperation in solving problems that arise in mutual relationships.

Just like Hohmann and Weikart (2005), Han and Kemple (2006) also find that adults (parents and educators) affect the development of social competences with proper support strategies, such as:

- Organizing the environment - organizing space and time.

- Naturalistic teaching strategies, which include situational learning (learning "here and now") and conflict mediation, which is a process of developing conflict solving skills though guided dialogue.

- Activity planning, which refers to structured and premeditated support strategies that adults use in interactions with children so that children could achieve certain goals and

- Interventions, which include adult actions with which they try to modify the already developed habits in children.

While children interact with materials, people, ideas and events and construct their own understanding of realty, adults observe and interact with children in order to discover how each individual child thinks and reasons. Educators strive to recognise special interests and skills of individual children and offer them adequate stimulation. Such role of adults is very complex and takes time to develop. 


\section{Purpose}

The purpose of the study was to find what conditions had to be ensured in the kindergarten to enable successful cooperative learning and to what extent such learning could be implemented at all. At the same time we would like to shed some light on support strategies that affect the quality of learning in kindergartens, which are:

- identifying spatial conditions that affect the quality of cooperative learning; kindergarten;

- illuminate the curriculum implementation or didactical image in the

- exploring the work dynamics, climate and communication between participants of the kindergarten educational process.

We posed the following fundamental research questions:

1. Regarding spatial planning:

- Is the space organised into clearly separated areas? use them?

- Are the aids and materials visibly placed in spots where children can reach and

- Are individual parts of the room organized so that children can play individually or in groups?

2. Regarding curriculum implementation, work dynamics, climate and communication between participants:

- Does the educator encourage children to express themselves during activities?

- Does the educator encourage children's social interactions during activities?

- Does the educator encourage children's independence during activities?

- Does the educator consider children's initiatives during activities?

- Is there an atmosphere of positive social interactions in the group?

- Is two-way communication prevalent?

- Does the educator strive to successfully solve conflicts?

- Do children help each other and offer explanations to each other?

- Do children in the group learn from one another?

- Do children ask many questions when working in groups?

\section{Methodology} study.

We used a descriptive method of empirical pedagogic research in form of a case

\section{Sample}

The survey was carried out on a group of 21 children aged 3 to 6 who visited the kindergarten; the group consisted of 13 boys and 8 girls. The unit employed an educator 
and an educator's assistant. Both had completed secondary education. The educator was 40 years old and the educator's assistant was 34 . The educator had 16 - 20 years of work experience and the assistant $6-10$ years.

\section{Data collection}

We used a qualitative technique of data collection. Data was collected through systematic observation with the use of a checklist. Observation was done without participation; the educator and her assistant were present in the unit the whole time. Observation was carried out during three consequent days in May 2010, when we observed children doing planned activities for 90 minutes each day. For the purposes of easier data collection, we divided our observation into three chapters. We focused on spatial planning, kindergarten work planning and curriculum implementation (didactical implementation, work climate and communication). In the introductory part we acquired general data on the kindergarten, which was followed by recording our observations in the "checklist".

\section{Analysis procedures}

Selected data was qualitatively analysed in regard to description, comparison, synthesis, causal explanation and understanding. In the checklist we noted $(\mathrm{X})$ the presence (YES, NO, NOT EVIDENT) of observed characteristics.

\section{Results and their Interpretation}

\section{Spatial planning}

The first stage was the analysis of spatial planning as a key factor for successful implementation of cooperative learning in the kindergarten. We paid attention to how the whole area and its specific parts were organized and which materials were present.

Checklist 1: Spatial planning

\begin{tabular}{|l|c|c|c|}
\hline \multicolumn{1}{|c|}{ AnPATIAL PLANNING } & YES & NO & $\begin{array}{c}\text { NOT } \\
\text { EVIDENT }\end{array}$ \\
\hline \multicolumn{1}{|c|}{ Answer } & $\mathbf{X}$ & & \\
\hline 1. Space is organized in clearly understood sub-areas. & $\mathbf{X}$ & & \\
\hline 2. Aids and materials are visibly placed in places where & & & \\
\hline $\begin{array}{l}\text { 3. Individual areas are organized so that children can play } \\
\text { alone or in groups. }\end{array}$ & $\mathbf{X}$. & $\mathbf{X}$ & \\
\hline $\begin{array}{l}\text { 4. Materials and equipment are safe, well maintained, } \\
\text { and suitable for children's size and development stage. }\end{array}$ & $\mathbf{X}$ & & \\
\hline 5. Children find the space attractive. & & $\mathbf{X}$ & \\
\hline 6. Different materials are provided: dough, sand, water... & $\mathbf{X}$ & & \\
\hline 7. The space is divided into clearly marked points of & & \\
\hline
\end{tabular}




\begin{tabular}{|l|l|l|l|}
\hline interest. & & & \\
\hline 8. The playroom gives an impression of tidiness. & & $\mathbf{X}$ & \\
\hline $\begin{array}{l}\text { 9. The kindergarten has permanent areas (eating area, } \\
\text { reading area, calm or silent area, hairdressing area). }\end{array}$ & $\mathbf{X}$ & & \\
\hline $\begin{array}{l}\text { 10. The kindergarten has temporary areas (technical area, } \\
\text { area with natural materials, musical area, art area, } \\
\text { cooking area). }\end{array}$ & $\mathbf{X}$ & & \\
\hline $\begin{array}{l}\text { 11. Points of interests are visible and easy to move } \\
\text { between. }\end{array}$ & $\mathbf{X}$ & & \\
\hline $\begin{array}{l}\text { 12. The playroom exudes a feeling of comfort, warmth } \\
\text { and familiarity. }\end{array}$ & $\mathbf{X}$ & & \\
\hline $\begin{array}{l}\text { 13. Children have plenty of toys and materials at their } \\
\text { disposal. }\end{array}$ & & $\mathbf{X}$ & \\
\hline
\end{tabular}

We found that the room was clearly divided into smaller areas, and that permanent playing areas and points of interests were well visible in the playroom. Children always had an eating area, reading area, cooking area, hairdressing area and a calm or silent area at their disposal. The only area missing from the permanent area group was an area with natural materials, as children do not always have access to sand, water or dough. In addition to permanent areas, children also had access to temporary areas, according to what the educator told us. They could choose from among the technical area, art area, musical area or natural materials. All points of interest were visible, children could freely move from one to another. The room appeared attractive and was mostly decorated with decorations made by children. To a lesser extent, works made by the educator and her assistant were visible as well. The playroom exuded a creative atmosphere. Among other things, the room enabled the children to play on their own or in groups. Children had access to aids and materials which were placed in spots where they could easily be reached. The materials and the equipment were well maintained, mostly new and suitable for children's size and development stage. Children had access to a number of different materials and toys. The playroom as a whole gave off a feeling of warmth, comfort and familiarity.

\section{Curriculum implementation, work dynamics, work atmosphere and communication among participants}

Checklist 2: Curriculum implementation, work dynamics, work atmosphere and communication among participants

\begin{tabular}{|l|c|c|c|}
\hline \multicolumn{4}{|c|}{ Curriculum implementation, work dynamics, work climate and communication } \\
\hline \multicolumn{1}{|c|}{ Answer } & YES & NO & $\begin{array}{c}\text { NOT } \\
\text { EVIDENT }\end{array}$ \\
\hline $\begin{array}{l}\text { 1. During the activities the educator encourages the children } \\
\text { to express themselves. }\end{array}$ & $\mathbf{X}$ & & \\
\hline $\begin{array}{l}\text { 2. During the activities the educator encourages children's } \\
\text { social interactions. }\end{array}$ & $\mathbf{X}$ & & \\
\hline $\begin{array}{l}\text { 3. During the activities the educator encourages children's } \\
\text { independence. }\end{array}$ & $\mathbf{X}$ & & \\
\hline 4. When children no longer cooperate, the educator gradually & $\mathbf{X}$ & & \\
\hline
\end{tabular}




\begin{tabular}{|c|c|c|c|}
\hline stops the planned act & & & \\
\hline $\begin{array}{l}\text { 5. If children require more time to finish a certain activity, the } \\
\text { educator allows it. }\end{array}$ & $\mathbf{X}$ & & \\
\hline $\begin{array}{l}\text { 6. During the activities the educator considers children's } \\
\text { initiatives. }\end{array}$ & $\mathbf{X}$ & & \\
\hline $\begin{array}{l}\text { 7. The educator observes the children and writes down her } \\
\text { observations. }\end{array}$ & & $\mathbf{X}$ & \\
\hline 8. Positive social interactions dominate in the group. & $\mathbf{X}$ & & \\
\hline 9. Children in the group are relaxed. & $\mathbf{X}$ & & \\
\hline 10. Children in the group are active. & $\mathbf{X}$ & & \\
\hline $\begin{array}{l}\text { 11. "Top-down" communication is prevalent - adults talk and } \\
\text { give orders, children listen. }\end{array}$ & & $\mathbf{X}$ & \\
\hline 12. Two-way communication is prevalent. & $\mathbf{X}$ & & \\
\hline 13. The educator strives to successfully solve conflicts. & $\mathbf{X}$ & & \\
\hline $\begin{array}{l}\text { 14. If children behave differently the educator uses suitable } \\
\text { educational procedures. }\end{array}$ & $\mathbf{X}$ & & \\
\hline 15. The educator seems honest. & $\mathbf{X}$ & & \\
\hline $\begin{array}{l}\text { 16. The educator communicates information clearly and } \\
\text { intelligibly. }\end{array}$ & $\mathbf{X}$ & & \\
\hline $\begin{array}{l}\text { 17. When communicating information the educator mentally } \\
\text { activates the participants. }\end{array}$ & $\mathbf{X}$ & & \\
\hline $\begin{array}{l}\text { 18. The educator is personally committed and provides real- } \\
\text { life comparisons. }\end{array}$ & $\mathbf{X}$ & & \\
\hline $\begin{array}{l}\text { 19. The educator responds to requests, offers information, and } \\
\text { establishes order. }\end{array}$ & $\mathbf{X}$ & & \\
\hline $\begin{array}{l}\text { 20. In order to overcome social conflicts, the educator uses } \\
\text { problem solving approaches. }\end{array}$ & & & $\mathbf{X}$ \\
\hline $\begin{array}{l}\text { 21. The educator has a calm approach to social conflicts and } \\
\text { confirms children's feelings. }\end{array}$ & $\mathbf{X}$ & & \\
\hline 22. Groups have a homogenous structure. & & $\mathbf{X}$ & \\
\hline 23. Groups have a heterogeneous structure. & $\mathbf{X}$ & & \\
\hline 24. The age of children in the group varies. & $\mathbf{X}$ & & \\
\hline 25. Children's knowledge and abilities within the group vary. & $\mathbf{X}$ & & \\
\hline $\begin{array}{l}\text { 26. Positive relations are predominant among group } \\
\text { members. }\end{array}$ & $\mathbf{X}$ & & \\
\hline 27. For successful work the educator uses praise/prizes. & $\mathbf{X}$ & & \\
\hline $\begin{array}{l}\text { 28. For less successful work the educator uses } \\
\text { punishments/reprimands. }\end{array}$ & & $\mathbf{X}$ & \\
\hline 29. Some children demonstrate aversion to group work. & $\mathbf{X}$ & & \\
\hline $\begin{array}{l}\text { 30. During group work children help each other and explain } \\
\text { things to each other. }\end{array}$ & $\mathbf{X}$ & & \\
\hline 31. Children in group learn from each other. & $\mathbf{X}$ & & \\
\hline 32. During group work children ask many questions. & $\mathbf{X}$ & & \\
\hline 33. During group work children talk a lot. & $\mathbf{X}$ & & \\
\hline $\begin{array}{l}\text { 34. Children explore, play, use materials and talk about what } \\
\text { they are doing. }\end{array}$ & $\mathbf{X}$ & & \\
\hline 35. Children solve problems they encounter. & $\mathbf{X}$ & & \\
\hline 36. Children adhere to agreements and rules. & & $\mathbf{X}$ & \\
\hline 37. In groups they talk about unpleasant and pleasant things & & & $\mathbf{X}$ \\
\hline
\end{tabular}




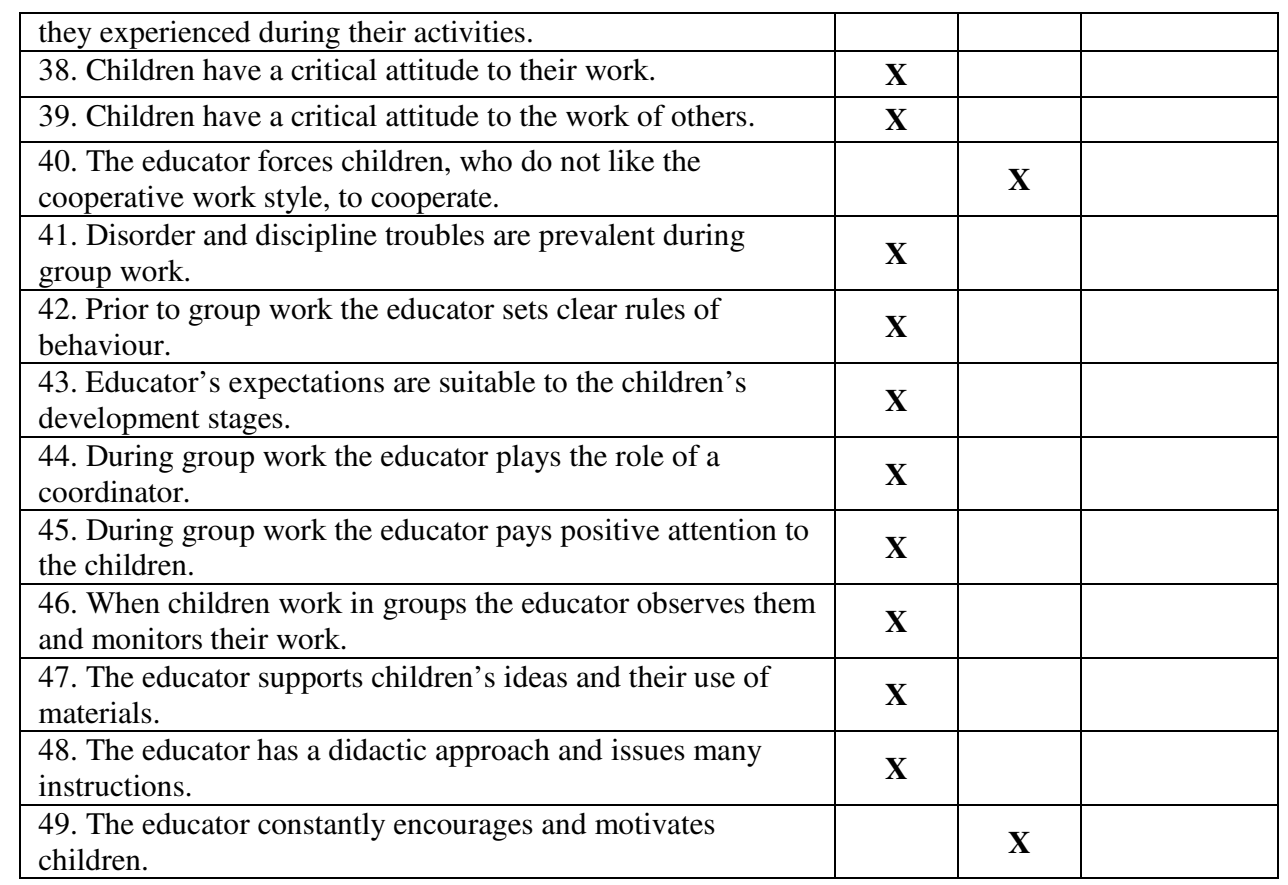

First, let us mention that the educator encouraged positive social interactions among children to the best of her abilities; she encouraged children and considered their initiatives while supporting their independence. When children stopped participating, the educator gradually ceased the planned activity. If children required more time to complete an activity, they got it. Positive social interactions were prevalent among the children; children in the group were relaxed. Two-way communication was prevalent over communication where adults speak and give orders while the child has to listen. The educator guided children in their work and observed them, she monitored their work and communication; however, she did not record her observations.

The educator used suitable educational measures and procedures for various types of child behaviour and strived to successfully solve conflicts. The children were given clear and understandable information, which activated them mentally. The educator was personally committed; she reacted suitably to children's questions and requests, offered information and constantly enforced order. In case of conflicts she did not use a problem solving approach, but merely calmed the children down.

Children formed their own groups; they chose individual activities freely and without coercion. In this way groups consisted of children of various ages and both sexes. There were disparities within groups regarding knowledge and skills. However, the most important fact was that in all groups there were positive relations among group members. The educator constantly monitored children and used praise if their work was well done. For less successful work she did not use punishment or reprimands, even though certain children quickly lost interest in certain activities and their work remained unfinished or lacking. Some children exuded a visible aversion to work. Such children immediately retreated to their own oasis, i.e. to one of the playing areas. The educator 
respected children's actions and wishes and did not force children to participate in activities they did not want to. Children who did not like the cooperative mode were not forced to participate. However, children participating in groups worked together, helped each other and explained things to each other, meaning that they learned from each other. During group work children asked many questions and talked to each other. A genuine working atmosphere existed in the playroom. Children talked a lot about what they were doing. When they were faced with problems, they solved them on their own or with the help of their peers. Some asked the educator or her assistant for help. Children more or less adhered to agreements and observed rules; however, there were certain objections, especially if their work motivation dropped. Children themselves did not talk about unpleasant or pleasant things that had happened during work unless encouraged by the educator.

Children were critical towards their own work and the work of others; they compared their knowledge and their work among themselves. Despite the fact that the educator had set clear rules of behaviour prior to doing individual activities, the children were partially unruly and individual children caused discipline problems.

\section{Instead of a conclusion}

When examining cooperative learning and support strategies in the kindergarten we discovered that children are active participants in the educational process, participating in suitable and interesting experiences through their actions and behaviour. The choice of materials and other participants in learning stems from children's internal motivations and problem solving skills. Cooperative learning starts when children think about their actions and discuss them with others. This in turn helps develop a child's understanding of the world, when the child tests ideas and seeks to answer question through its own activities. Development of such actions and such ways of thinking is the development of thoughts and understanding, as the motivation to learn stems from the child itself. Solutions might seem unrecognisable to adults, however, a child's thinking and creative process is a way for him or her to understand their world.

This leads us to the conclusion that cooperative learning is a creative process where children combine materials, ideas and experience to achieve new effects.

Thus, the motivation for activities comes from the children themselves, they themselves choose the materials and explore them with all their senses, they learn through immediate experience with items and they use their own words to talk about their experience.

The role of adults in cooperative learning is providing suitable materials for the children to use. Adults also prepare the space and set the time for activities. During the learning process they monitor and encourage the children. This way children and adults interact with each other, form partnerships, invent and explore together.

In our study of the conditions for providing successful cooperative learning in the kindergarten we focused mostly on spatial planning and the didactical aspect. By highlighting the factors for cooperative learning of children in the kindergarten we used concrete cases to identify support strategies for development of cooperative learning. 
We found that the space was suitably equipped, attractive to children as it was designed to their liking and equipped with a number of playing areas and materials. Such playrooms offer excellent conditions for creating a working atmosphere and consequently for achieving positive results.

We also found that the educator monitored and encouraged the children in their activities, if required, she provided guidance, but the children were nevertheless given much independence. On general, positive social interactions were prevalent in the group, with an atmosphere of creativity. The children worked alone or in groups of their choosing.

In the end we can sum up that the conditions for developing cooperative learning in the kindergarten are adequate, educators and children favour such activities and are happy to engage in them. Children achieve their own work results; educators do not limit or hinder them. Learning experience acquired in this manner is more solid and more pleasant compared to traditional learning with educator's guidance.

To sum up, the main result is that the previously mentioned methods can be used to avoid conflicts between adults and children and replace them with cooperative experiences. If adults understand the child's need for activities, they participate in encouraging and widening the circle of activities initiated by the child and do not try to guide a child's behaviour. Adults must accept children's inquisitive behaviour as something normal and desired and not try to undermine or eliminate it, so as not to negatively affect the lives of children. During active participation children are allowed to make mistakes and adults should not correct them. This way the children will develop a feeling of competence because they have adult support in their actions, choices, explorative behaviour, etc.

\section{References}

1. Bahovec, D., E., idr. (1999). Kurikulum za vrtce. Ljubljana: Ministrstvo za šolstvo in šport: Zavod RS za šolstvo.

2. Bahovec D., E. in Kodelja, Z. (1996). Vrtci za današnji čas. Ljubljana: Center za kulturološke raziskave pri Pedagoškem inštitutu.

3. Han, H. S.in Kemple, K. M. (2006). Components of Social Competence and Strategies of Support: Considering What to Teach and How. V: Early Childhood Education Journal, Vol. 34, no. 3, December 2006. 241-246.

4. Hansen K. in Kaufmann R. (2000). Korak za korakom. Ljubljana: Pedagoški inštitut.

5. Hohmann M. in Weikart D. (2005). Vzgoja in učenje predšolskih otrok. Ljubljana: DZS.

6. Kozel, J in Kmetec, E. (2001/02). Od individualnega k sodelovalnemu učenju. Educa, $(5 / 6)$, str. $55-56$

7. Kroflič, R. (2005). Strokovna avtonomija vrtca in vzgojiteljice. V: Strokovna avtonomija vzgojitelja (str. 33-37). Ljubljana: Skupnost vrtcev Slovenije.

8. Krek, J. (1995). Bela knjiga o vzgoji in izobraževanju v Republiki Sloveniji. Ljubljana: Ministrstvo za šolstvo in šport.

9. Lepičnik Vodopivec, J. (2005). Avtonomija vzgojiteljice in vzgojitelja v odnosu s starši. V: Strokovna avtonomija vzgojitelja (str. 38-47). Ljubljana: Skupnost vrtcev Slovenije. 
10. Marentič-Požarnik, B. (2000). Psihologija učenja in pouka. Ljubljana: DZS.

11. Marjanovič Umek, L. (ur) (2010). Otrok v vrtcu. Maribor: Založba Obzorja.

12. Peklaj, C. (1994). Od individualnega k sodelovalnemu učenju - model šestih ogledal v razredu. Educa, (3), str. $152-167$.

13. Peklaj, C. (1998). Spodbujanje sodelovanja - različni pristopi k razvoju sodelovalnih veščin v razredu. Sodobna pedagogika, (3), str. 287 - 299.

14. Peklaj, C. (2001). Sodelovalno učenje ali kdaj več glav več ve. Ljubljana: DZS.

15. Skupna evropska načela za kompetence in kvalifikacije učiteljev (2004). Pridobljeno 22. 2. 2007, http://www.pef.uni-lj.si/bologna/dokumenti/eu-common-principles-slo.pdf

16. Učenje v vrtcu (2006). Pridobljeno 18.1.2007, http://www.pef.unilj.si/strani/oddelki/ (2pp-ucenje-vrtec.rtf)

Metodički obzori 6(2011)2

Izvorni znanstveni rad

UDK: $373.24 .02 / .03$

Primljeno: 5. 1. 2011.

\section{SURADNIČKO UČENJE I STRATEGIJE PODRŠKE U VRTIĆU}

Izv. prof. dr. sc. Jurka Lepičnik Vodopivec,

Pedagoška fakulteta

Univerza v Mariboru (Slovenia)

e-mail: jurka.lepicnik@uni-mb.si

\section{Sažetak}

U svojem smo radu istražile značajke suradničkog učenja i strategija podrške u vrtiću. Tipično svojstvo aktivnog učenja jest konstantno stvaranje pogodnog okruženja koje potiče učenje. Stimulirajuće okružje jest okružje u kojem prevladavaju pozitivne društvene interakcije i međusobno povjerenje. U takvom okruženju djeca razvijaju socijalne vještine i kompetencije, što znatno utječe na njihov razvoj. Takve uvjete u vrtiću stvaraju odrasli ljudi koji teže prepoznati specifične interese i vještine svakog djeteta, te im pružaju odgovarajući poticaj i inicijativu za suradničko učenje. Odgajatelji podržavaju suradničko učenje djece kroz posebne strategije podrške, npr. uređujući prostor i okružje, uspostavljajući ozračje pozitivne socijalne interakcije, ohrabrujući dječje aktivnosti te razmatrajući njihove interese i inicijative i promišljajući o istima. podrške

Ključne riječi: Suradničko učenje, predškolsko dijete, vrtićke strategije 